\title{
Trace Elements in Lake Baikal: Current Status, Forecast and Monitoring Problems
}

\author{
V. A. Vetrov \\ Institute of Global Climate and Ecology of Roshydromet and RAS, Moscow, Russia \\ Email: vetrov.igce@mail.ru
}

How to cite this paper: Vetrov, V.A. (2018) Trace Elements in Lake Baikal: Current Status, Forecast and Monitoring Problems. Journal of Geoscience and Environment Protection, 6, 66-82. https://doi.org/10.4236/gep.2018.63007

Received: March 1, 2018

Accepted: March 29, 2018

Published: April 2, 2018

\begin{abstract}
Assessment of the current status of Lake Baikal proved to be based on changes in natural ("preindustrial") chemical content in basic abiotic and biological compartments of the Lake geosystem. This approach was used to evaluate background "base-line levels" of 6 major and about 50 minor and trace elements in the Lake Baikal water body using a number of most reliable data reported within 1992-2012. In terms of environment geochemistry Baikal is one of the purest water reservoirs on the Earth. A simple mass balance model was proposed for assessing possible anthropogenic impact on Baikal water geochemistry. Estimations of change trends showed that only for $\mathrm{Na}^{+}, \mathrm{SO}_{4}^{2-}, \mathrm{Cl}^{-}$ and Mo growth rate of their average concentrations in the Lake occurred to be $1 \%, 3 \%, 7 \%$ and $2 \%$ in every 10 years. Space-time monitoring schedules for all water body compartments of the Lake are proposed as well as similar monitoring programs for tributaries, precipitations, bottom sediments, aquatic biota.
\end{abstract}

\section{Keywords}

Lake Baikal, Environmental Geochemistry, Status, Base-Line Concentrations, Trace Elements, Change Trends, Forecast, Mass Budget, Anthropogenic Impact, Eco-Geochemical Monitoring, Monitoring Programs

\section{Current Status: Environmental Geochemistry}

\subsection{Introduction}

Assessment of the current status of the total biosphere and its components, and forecast of potential man-made changes in them should be based on the knowledge of background content of elements in natural environments [1] [2] [3]. When selecting evaluation criteria we proceed from the concept that natural systems fall into several categories, depending on the level man-made impact. 
[4]:

Lake Baikal, as a unique ecological object should be referred to the category of virgin territories. From the viewpoint of environmental geochemistry, assessment of the current status of the Lake should be based on changes in natural ("preindustrial") chemical content in basic abiotic and biological constituents of the Lake geosystem. Changes in the chemical budget of the Lake might begin since early 1940-s. These considerations were the basis of the studies implemented during 1975-2013 to evaluate background beogeochemical levels and chemical balance of Lake Baikal [5] [6].

\subsection{Geographic Condition}

Lake Baikal is the center of a region encompassing a drainage basin with the area of about 540 thousand $\mathrm{km}^{2}$ (Figure 1). The Lake consists of three morphologically distinguished basins: south, middle and north. Baikal's area is $31,600 \mathrm{~km}^{2}$, water volume $21,700 \mathrm{~km}^{3}$, length $636 \mathrm{~km}$, average width $48 \mathrm{~km}$, maximum depth $1620 \mathrm{~m}$, average depth about $700 \mathrm{~m}$. Water income $\left(70.3 \mathrm{~km}^{3} / \mathrm{year}\right)$ is mainly formed by rivers $(83 \%)$, precipitation on the Lake surface $(13 \%)$ and underground inflow (3\%) [7].

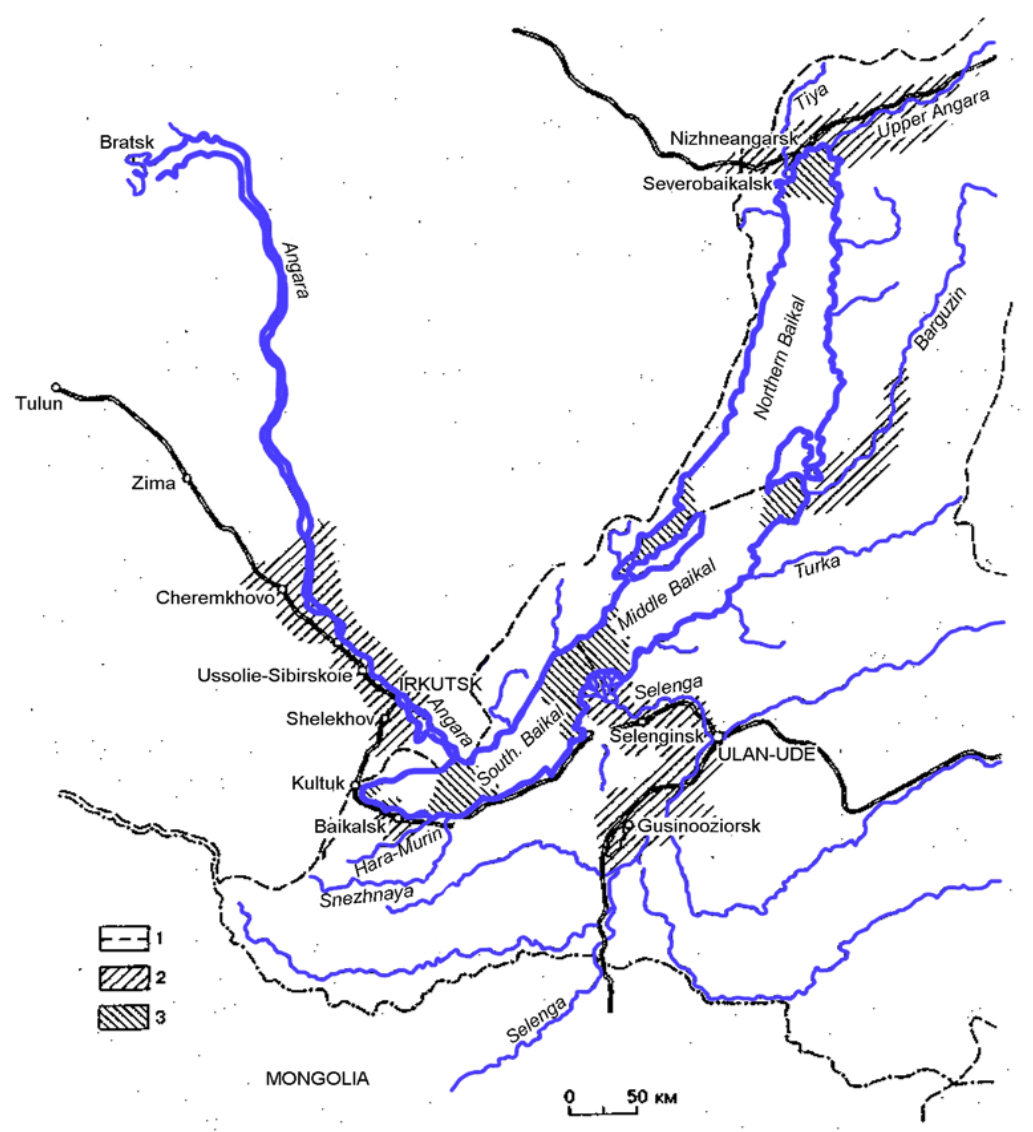

Figure 1. Schematic map of the Lake Baikal region. 1-the boundary of the catchment area; 2-areas of intensive anthropogenic releases; 3 -areas of potential anthropogenic impact on the Lake Baikal waters. 
Over 300 streams fall into the Baikal, the Angara River flowing out of the Lake. Catchments of the Selenga, Barguzin, Upper Angara and Turka rivers take over $90 \%$ of the drainage area. The arbitrary water exchange periods are 509 years in the North Baikal, 245 years in the Middle Baikal, 89 years in the South Baikal, 309 years for the whole Lake. There is a long-term stable transfer of chemicals and pollutants from the northern basin to the medium and southern ones; backward transfer is highly unlike. The period of water column takeover is estimated as 11 years or longer [8].

\subsection{Economy and Environment Pollution Sources}

The economy of the region is represented by many branches of energy-consuming industries such as non-ferrous metallurgy, mining, chemical, pulp and paper, forest, wood-manufacturing, fuel and energy production. Enterprises of these industries are responsible for releases into environment wide spread pollutants such as dust, soot, sulplur and nitrogen oxides, toxic metals, etc. Figure 1 shows areas of intensive economic development in the region as well as zones of potential anthropogenic impact on the Lake Baikal waters.

\subsection{Methodology}

The objective of the paper is to evaluate the modern environmental/geochemical status of Lake Baikal and the trends in potential changes in the status in the near decades as the result of economic activity in the region. These goals have been achieved through studying the content of about 30 trace elements in Baikal waters and major constituents of the Lake chemical budget (tons/year), showed on Figure 2 [5]:

$$
\Delta \mathrm{P}=\mathrm{P}_{\text {in }}-\mathrm{P}_{\text {out }}=\left(\mathrm{P}_{\mathrm{r}}+\mathrm{P}_{\mathrm{u}}+\mathrm{P}_{\mathrm{a}}+\mathrm{P}_{\mathrm{T}}\right)-\left(\mathrm{P}_{\mathrm{A}}+\mathrm{P}_{\mathrm{S}}\right)
$$

where:

$\Delta \mathrm{P}$-the so called "balance mismatch" (discrepancy of the budget) $=$ the difference between annual input Pin and output Pout fluxes;

$\mathrm{Pa}$-atmospheric fallout on Lake surface;

$\mathbf{P}_{\mathrm{T}}$-direct manmade (industrial) effluents to Lake;

$\mathbf{P}_{\mathbf{r}}, \mathbf{P}_{\mathbf{u}}$-inflow with river and underground runoff;

$\mathbf{P}_{\mathrm{b}}$-contribution of biota residues to deposition to bottom sediments;

$\mathbf{P}_{\mathrm{A}}$ - outflow through Angara river;

$\mathbf{P}_{\mathrm{S}}$-deposition to bottom sediments;

Methodology of studies, reported in this part I of the paper, included the following main tasks [9]:

1) sampling of natural environment objects: atmospheric aerosol, precipitation (snow and rain), water from the Lake and tributaries, bottom sediments, aquatic biota;

2) determining of atmospheric emissions and sewage discharges from the Baikalsk and Selenginsk pulp-and-paper mills (BPPM and SPPM);

3) laboratory element analysis of samples; 


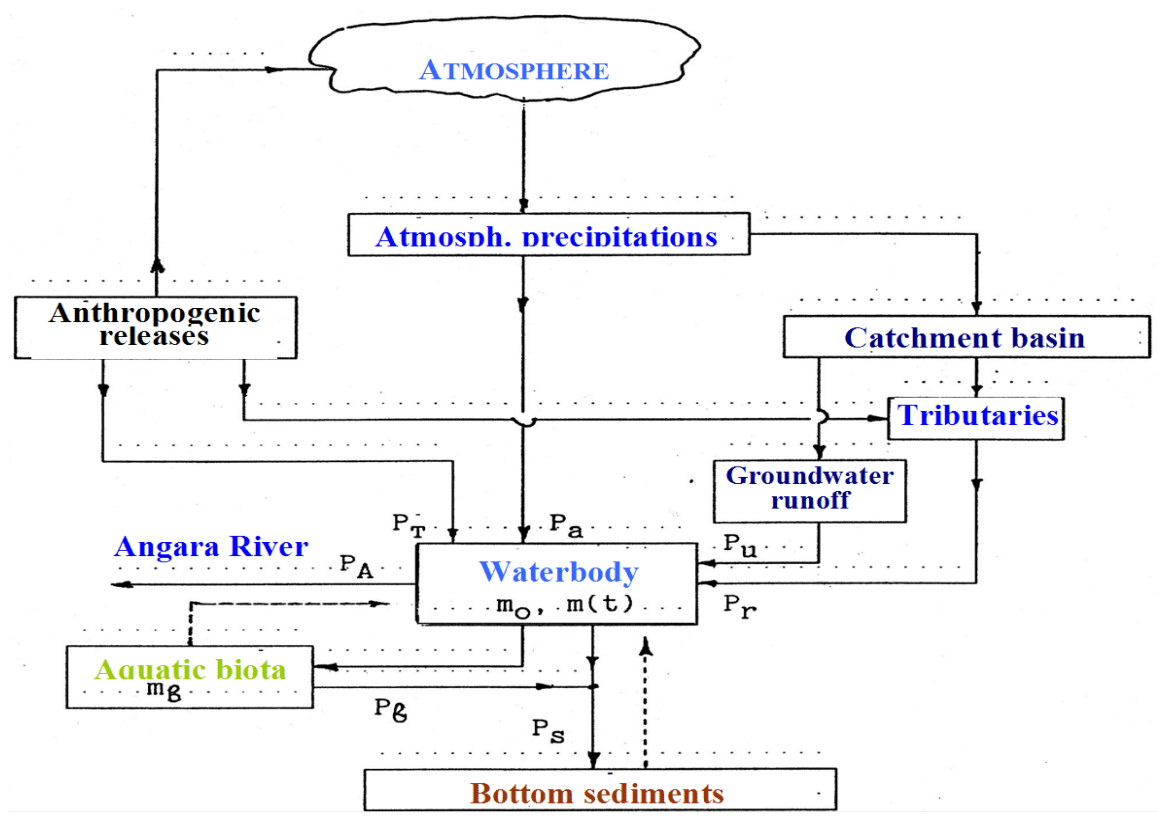

Figure 2. Major pathways of chemical elements in Lake Baikal watershed.

4) estimation of baseline concentrations of elements in natural environments, biota, industrial releases using both data from our studies, and published data obtained by other investigators.

\subsection{Results}

\subsubsection{Trace Elements in the Waterbody}

Hydrochemical pattern of Baikal waters is formed mainly by river and underground flows. Baikal waters are classified as weakly mineralized carbon-type soft waters [10]. Due to long water residence time and sufficient circulation within each basin, major ions are generally homogeneously distributed within the Lake waterbody.

In our last work [6] we evaluated contents of 6 major ( $\mathrm{Si}, \mathrm{Ca}, \mathrm{Mg}, \mathrm{K}, \mathrm{Na}, \mathrm{F}$ ) and about 50 minor and trace elements $(\mathrm{Li}, \mathrm{Be}, \mathrm{B}, \ldots \mathrm{Pb}, \mathrm{Th}, \mathrm{U})$ in the Lake Baikal water body by analysing a number of most reliable data reported within 1992-2012 [5] [6] [10]-[16]. Table 1 demonstrate part of recommended background ("base-line") concentrations of selected elements in the form of confidence limits' range for each element concentrations [6]. Presented base-line values in Baikal waters being compared with well-known reference freshwater reviews [17] [18] [19] [20] show that Baikal water can serve as a model of unpolluted global fresh water and Lake Baikal is one of the purest water reservoirs on the Earth.

As a rule, due to asymmetry statistical distribution of element concentrations their variability was far beyond estimated analytical uncertainties. Statistical analysis of selected data on different Lake basins and depth profiles indicates a relatively homogeneous distribution of elements in the Lake.

"Solid phase" concentrations of most elements were less $10 \%$ of the total. All 
Table 1. Background ("base-line") levels of some major and trace elements in Lake Baikal, $\mu \mathrm{g} / \mathrm{l}$.

\begin{tabular}{cccc}
\hline & Confidence limits range & \multicolumn{2}{c}{ Background concentrations in fresh surface waters } \\
\cline { 3 - 4 } & {$[6][11][13]$} & Yaroshevsky, Korzh & $\begin{array}{c}\text { Markert, Gaillardet [19] } \\
{[17][18]}\end{array}$ \\
\hline $\mathrm{Na}$ & $3.3-3.6$ & $5-5.3$ & 5 \\
$\mathrm{~K}$ & $0.9-1.0$ & $1.5-2$ & 2 \\
$\mathrm{Ca}$ & $15.5-16.4$ & $12-14$ & 2 \\
$\mathrm{Al}$ & $0.04-1.0$ & $50-160$ & $30-200$ \\
$\mathrm{Cr}$ & $0.03-0.09$ & 1 & $0.7-1$ \\
$\mathrm{Mn}$ & $0.01-0.53$ & $8-10$ & $5-34$ \\
$\mathrm{Fe}$ & $0.1-1.6$ & 40 & $66-500$ \\
$\mathrm{Cu}$ & $0.2-1$ & $1.5-7$ & $1.5-3$ \\
$\mathrm{Zn}$ & $0.4-4.3$ & $0.15-20$ & $0.6-5$ \\
$\mathrm{As}$ & $0.3-0.5$ & $1.7-2$ & $0.5-0.6$ \\
$\mathrm{Mo}$ & $0.8-1.5$ & $0.5-1$ & $0.4-1$ \\
$\mathrm{Hg}$ & $0.0001-0.0014$ & 0.07 & 0.1 \\
$\mathrm{~Pb}$ & $0.03-0.06$ & $0.1-1$ & $0.08-3$ \\
\hline & & &
\end{tabular}

presented results are total element concentrations in the Lake water, i.e. the sum of both dissolved and particulate matter.

\subsubsection{Trace Elements in Tributary Waters.}

Studies of trace elements concentrations in the Selenga River and 16 other tributaries were undertaken in 1974-1983. Water and chemical runoff from the studied tributaries contribute more than $80 \%$ to annual river inflow to the Lake [5].

A part of most reliable average DF concentrations $\mathrm{Cr}$ of some major ions and metals in river waters of the Selenga River and other tributaries obtained in 1974-1983 surveys are given in the Table 2 [5]. These data were used to calculate annual river inflow $\operatorname{Pr}$ of these chemicals to the Lake (Figure 2).

\subsubsection{Atmospheric Fallout of Chemical Elements on the Lake Baikal Surface}

Methodological approach to determining atmospheric fallout of chemicals on the Lake Baikal surface and adjacent watershed area (Figure 2) consisted in measuring elements both in dissolved and particulate forms (DF and PF) in snow deposited on the Lake ice cover in the end of winter period (March-April). For this purpose several snow sampling surveys were made in 1974-1983 on the Baikal ice cover and surrounding area [5] (Table 3). Concentrations of DF of trace elements and major ions $\mathrm{Na}^{+}, \mathrm{SO}_{4}^{2-}, \mathrm{Cl}^{-}$in snow and rain precipitations on the Lake were in good agreement with available world data for the most clear precipitations in rural highland continental regions [21] [22]. 
Table 2. Average concentrations Cr, of some major ions and trace elements (DF) in the Selenga river and in other tributary waters and river flow to the Lake Pr [5].

\begin{tabular}{cccc}
\hline & \multicolumn{2}{c}{ Average concentrations $\mathrm{C}_{\mathbf{r}}, \mu \mathrm{g} / \mathrm{l}$} & $\begin{array}{c}\text { Chemical runoff } \\
\mathrm{P}_{\mathrm{r}} \text {, ton } / \text { year }\end{array}$ \\
\cline { 2 - 3 } & Selenga & Other tributaries & \\
$\mathrm{Na}^{+}$ & \multicolumn{2}{c}{ Major ions } \\
$\mathrm{SO}_{4}^{2-}$ & 5800 & 3600 & $276 \times 10^{3}$ \\
$\mathrm{Cl}^{-}$ & 17,000 & 6000 & $673 \times 10^{3}$ \\
& 2200 & 780 & $87 \times 10^{3}$ \\
$\mathrm{Al}$ & & Trace elements & 2244 \\
$\mathrm{Cr}$ & 36 & 40 & 21 \\
$\mathrm{Mn}$ & 0.22 & 0.5 & 306 \\
$\mathrm{Fe}$ & 3.3 & 7 & 2740 \\
$\mathrm{Co}$ & 22 & 70 & 3,0 \\
$\mathrm{Cu}$ & 0.05 & 0.05 & 70 \\
$\mathrm{Zn}$ & 0.64 & 1.7 & 309 \\
$\mathrm{Mo}$ & 6.2 & 4.3 & 74 \\
$\mathrm{~Pb}$ & 0.8 & 1.7 & 36 \\
\hline
\end{tabular}

Table 3. Atmospheric fallout of trace elements to Lake Baikal in 1976-1983 [5].

\begin{tabular}{|c|c|c|c|c|}
\hline \multirow[b]{2}{*}{ Element } & \multicolumn{2}{|c|}{$\begin{array}{l}\text { Concentration of DF in precipitation } \\
\qquad \mathrm{C}_{\mathrm{a}}, \mu \mathrm{g} / \mathrm{l}\end{array}$} & \multicolumn{2}{|c|}{$\begin{array}{l}\text { Annual flux on the Lake surface } \\
\qquad \mathbf{P}_{\mathrm{a}} \text {, ton/year }\end{array}$} \\
\hline & $\begin{array}{l}\text { Average conc. in } \\
\text { Baikal area }\end{array}$ & $\begin{array}{c}\text { Rural continental } \\
\text { areas (background) } \\
{[24][25]}\end{array}$ & $\begin{array}{l}\text { Particulate forms } \\
\qquad(\mathrm{PF})\end{array}$ & $\begin{array}{l}\text { Dissolved forms } \\
\text { (DF) }\end{array}$ \\
\hline $\mathrm{Na}$ & 125 & $90-56,000$ & 580 & 1160 \\
\hline $\mathrm{Al}$ & 43 & - & 3600 & 400 \\
\hline $\mathrm{V}$ & 2.0 & - & 10 & 19 \\
\hline $\mathrm{Cr}$ & 0.08 & $0.1-12$ & 26 & 0.73 \\
\hline Mn & 3.8 & - & 100 & 35 \\
\hline $\mathrm{Fe}$ & 3.8 & $16-4000$ & 3600 & 35 \\
\hline Co & 0.026 & $0.04-4$ & 1.8 & 0.24 \\
\hline $\mathrm{Cu}$ & 1.6 & - & - & 15 \\
\hline $\mathrm{Zn}$ & 2.0 & $10-260$ & 38 & 19 \\
\hline As & 0.06 & $0.007-0.1$ & 2.7 & 0.6 \\
\hline Mo & 0.3 & - & - & 3 \\
\hline $\mathrm{Pb}$ & 1 & - & 10 & 10 \\
\hline
\end{tabular}


Since average DF concentrations of most elements in atmospheric precipitations on the Lake surface were lower or close to the water base-line levels (Table 1) technogenic pollution of the atmosphere over the Lake could not noticeably affect concentrations of trace elements in the Lake water body.

\subsubsection{Trace Elements in the Lake Sediments}

Concentrations of about 30 elements were measured in $10 \mathrm{~cm}$ natural sediment cores sampled in 1961-1981 at 37 stations located in all deep-water areas of the Lake [5]. Ranges of average concentrations of some elements in pelit sediments obtained in all basins are shown in Table 4. The element composition of upper layer of pelit sediments over the Lake seems to be fairly homogeneous all over the Lake bottom. No significant technogenic impact was found on elements content of fine-alevrit sediments in BPPM discharge area and Selenga delta shoal as compared with element content of deep water sediments.

The element composition of an upper layer of Baikal sediments certainly reflects background sediments geochemistry in oceanic clays [23] [24].

\subsubsection{Trace Elements in Baikal Biota}

The main objective to study trace elements concentrations in Baikal water organisms was to assess:

1) accumulation of chemical elements by different species of water organisms and their perspectives to serve as bioindicators for biogeochemical monitoring of trace elements in the Lake water body;

Table 4. Element composition of Lake Baikal sediments [5].

\begin{tabular}{|c|c|c|c|c|c|}
\hline Element & $\begin{array}{l}\text { Pelite silt in deep water } \\
\text { areas of Lake Baikal }{ }^{1)}\end{array}$ & $\begin{array}{l}\text { The Selenga River shoal } \\
(\text { fine silt }+ \text { alevrit })^{2)}\end{array}$ & $\begin{array}{l}\text { The BPPM discharge area } \\
\text { (fine silt })^{3)}\end{array}$ & $\begin{array}{l}\text { Oceanic clays } \\
{[25][26]}\end{array}$ & $\begin{array}{l}\text { Annual flux to Baikal } \\
\text { sediments } \mathbf{P}_{\mathrm{S}} \text {, ton/year }\end{array}$ \\
\hline \multicolumn{6}{|c|}{ MAJOR ELEMEHTS (\%) } \\
\hline $\mathrm{Na}$ & $1.2-1.4$ & - & $1.1-1.4$ & $1.35-4$ & $24 \times 10^{3}$ \\
\hline $\mathrm{Al}$ & $4.7-6.1$ & - & - & $5.4-9.2$ & $110 \times 10^{3}$ \\
\hline Mn & $0.13-0.50$ & $0.03-0.09$ & $0.04-0.08$ & $0.30-0.67$ & $6.6 \times 10^{3}$ \\
\hline $\mathrm{Fe}$ & $5.0-6.6$ & $1.9-3.7$ & $4.0-4.8$ & $3.8-6.5$ & $110 \times 10^{3}$ \\
\hline \multicolumn{6}{|c|}{ TRACE ELEMENTS (ppm) } \\
\hline $\mathrm{V}$ & $160-180$ & $40-150$ & $150-330$ & $100-140$ & 330 \\
\hline $\mathrm{Cr}$ & $60-130$ & $40-90$ & $120-150$ & $62-90$ & 160 \\
\hline $\mathrm{Cu}$ & - & $12-30$ & $20-40$ & $130-250$ & 90 \\
\hline $\mathrm{Zn}$ & $80-140$ & $220-340$ & $60-100$ & $130-165$ & 200 \\
\hline As & $14-53$ & - & - & $10-13$ & 60 \\
\hline Mo & $(<1)-5$ & - & - & $10-27$ & 5.4 \\
\hline $\mathrm{Cd}$ & $0.2-0.4$ & $(<0.1)-0.27$ & $(<0.05)-0.11$ & $0.42-0.56$ & 0.65 \\
\hline $\mathrm{Hg}$ & 0.07 & $(<0.02)-0.18$ & $0.007-0.014$ & $0.04-0 . n$ & 0.14 \\
\hline $\mathrm{Pb}$ & $14-25$ & $12-21$ & $9-12$ & $40-80$ & 38 \\
\hline
\end{tabular}


2) role of biota in removing of trace elements from the Lake ( $\mathrm{Pb}$ in Figure 2).

In 1979-1987 contents of more than 20 trace elements were studied in plankton, benthos species (hammaridae, polifera, molluscs) and most common food fish using the full set of AE-, AA- and NA-analytical techniques [5]. Estimated average concentrations were in good agreement with world biogeochemical data on uncontaminated fresh water ecosystems. Among all 29 investigated metals only $\mathrm{Rb}$ revealed a tendency to increasing bioavailability from lower trophic levels to upper ones. Estimates of metal flux rates to bottom sediments $(\mathrm{Pb}$ in Figure 2) were calculated on the basis that deposition of autochtonic organic matter to sediments was equal to 800.000 ton/year (dry mass) [25].

Our findings indicate that uptake of some metals ( $\mathrm{Zn}, \mathrm{Ag}, \mathrm{Cd}, \mathrm{Sn}, \mathrm{Sb}, \mathrm{Hg}, \mathrm{Pb}$, $\mathrm{U})$ by phytoplankton can be a significant route to their removal from the water body to the bottom sediments together with depositing suspended organic matter. In general, amounts of trace elements in aquatic biota consist minor fractions (less than $0.1 \%$ ) of their total inventories in the Lake water body.

The accumulation of elements in raw biomass is estimated by the coefficient.

$\mathrm{K}_{\mathrm{a} 0}=$ concentration in raw biomass $(\mathrm{ppm}) /$ concentration in water $(\mu \mathrm{g} / \mathrm{l})$.

1) range of average concentrations in three main basins;

2) range of average concentrations for two clusters of samples- "fine silt + alevrit" and "almost fine silt";

3) range of concentrations in all samples;

Tissues and organs of Baikal fish are strong concentrators of trace elements (Ka0 103 - 104) and thus represent convenient objects for monitoring of trace elements in Lake water. Especially active accumulate Zn (gills, liver, skin gonads), Se (liver) and $\mathrm{Hg}$ (muscles and all organs).

\subsubsection{Trace Elements in Releases of Cellulose Pulp and Paper Mills}

Atmospheric emissions from the BPPM were studied in 1977-1982 with the objective to determine deposition of dust (hard particles, $\mathrm{HP}$ ), SO42-, $\mathrm{Cl}-, \mathrm{Na}+$ and trace elements on South Baikal surface and nearby coastal area. Results of the studies showed, that HP and other chemical pollutats from the BPPM emissions significantly contaminated an area up to $1000 \mathrm{~km} 2$ shared approximately in two equal parts between Lake surface and coastal area. The BPPM emissions contributed to the total deposition on the nearby Lake surface as following: $\mathrm{HP}-10 \%$; $\mathrm{SO}_{4}^{2-}-3 \%-7 \%$; $\mathrm{Na}-$ more than $25 \%$.

In the early 1980-s BPPM discharges contributed from 0,n\% ( $\mathrm{Al}, \mathrm{Fe}, \mathrm{Co}, \mathrm{Ni}$, $\mathrm{Cu}, \mathrm{Mo}, \mathrm{Ba}, \mathrm{Pb})$ to $8 \%(\mathrm{Mn})$ to annual inflow of elements $\mathrm{DF}$ to the Lake. At the same time major chemicals and trace elements in SPM discharges did not considerably contribute to the Selenga chemical runoff.

\subsubsection{General Assessment of Lake Baikal Current Status}

A general assessment of Lake Baikal current status can be based on the criteria of corresponding chemical elements' levels in the Baikal region environments to 
the unpolluted natural geochemistry of waters, soils, sediments etc. which were inherent in the "re-industrial" era. Our approach to assessing a man-made impact on the biogeochemical status of the Baikal geosystem is to answer two questions:

1) What element concentrations in geosystem compartments could be adopted as background ("base-line") levels, that is regional "clarks" ("fersms")?

2) What excess of background level (regional "clark/fersm") can be considered as significant one, that could indicate a real change in regional geochemistry, that is a "pollution"?

Assessment of current status of the Lake water geochemistry can be significantly simplified if it would be based on an analysis of the element mass budget in the Lake water body which serves as a central part of the Lake geosystem, accumulating all kinds of pollutants from the Baikal water catchment basin (form. 1, Figure 2) [5].

\section{Forecast of Element Baseline Levels in Lake Water}

\subsection{The Mass Budget Model}

The methodology of this part was to develop a balance model for estimation trends of element baseline levels in the Lake waters in the past (epignosis) and the future (forecast).

Table 5 demonstrate a part of our estimates of mass budget components for $\mathrm{SO}_{4}^{2-}, \mathrm{Cl}^{-}, \mathrm{Na}$ and DF selected trace metals in the Baikal water body. A simple analysis of input/output flows of the element mass in the Lake $(\mathrm{m} 0, \mathrm{~m}(\mathrm{t})$, Figure 2 , form. 1) shows that the outflow parts cannot be reliably evaluated due to lack of data on removing dissolved substances from the Lake water body into bottom sediments through absorption on settling particulate matter $(\mathrm{Pb}$ in Figure 2). On the other hand, sedimentation fluxes of all metals, except $\mathrm{Na}, \mathrm{Zn}, \mathrm{Mo}, \mathrm{Pb}$ exceed respective total inflow values, often by many times. This means that the river inflow of hard (particulate) matter provides the bulk amount of an element mass depositing to the Lake sediments. In the case of SO42, $\mathrm{Cl}-, \mathrm{Na}$ and $\mathrm{Mo}$ there are enough reasons to believe that their total mass inflow exceed total outflow including sedimentation of hard particles.

A simple mass balance model was proposed for assessing possible anthropogenic effects on Baikal water geochemistry [5]:

$$
\frac{m(t)}{m_{0}}=\frac{\Delta P}{\lambda_{A} m_{0}}-\left(\frac{\Delta P}{\lambda_{A} m_{0}}-1\right) \cdot \exp \left(-\lambda_{A} t\right)
$$

where:

$m(t)$-total mass of a chemical conservative substance in the Lake waterbody (inventory, tons) at the time $t$, year;

$m_{0}$-the same at the zero time $t=0$;

$\Delta P$-netto substance mass input to the waterbody, tons/year (form. 1, Table 5); 
Table 5. Components of the mass budget of some major ions and trace metals in the Baikal water body in 1970 - 1980-s.

\begin{tabular}{|c|c|c|c|c|c|c|}
\hline \multirow{2}{*}{ Sub-stance } & \multirow{2}{*}{$\begin{array}{c}\begin{array}{c}\text { Inventory } \\
\text { in the Lake, ton }\end{array} \\
\text { Water body } \\
\mathrm{m}_{\mathrm{o}}, \mathrm{m}(\mathrm{t})\end{array}$} & \multirow{2}{*}{$\begin{array}{c}\begin{array}{c}\text { Input } \\
\text { ton/year }\end{array} \\
\text { Total } \\
\mathbf{P}_{\text {in }}\end{array}$} & \multicolumn{3}{|c|}{$\begin{array}{l}\text { Output } \\
\text { ton/year }\end{array}$} & \multirow{2}{*}{$\begin{array}{c}\Delta P=P_{\text {in }}-P_{\text {out }} \\
\text { ton/year }\end{array}$} \\
\hline & & & $\begin{array}{c}\text { Angara outflow } \\
\mathbf{P}_{\mathrm{A}} \\
\end{array}$ & $\begin{array}{c}\text { Sedimentation } \\
\mathbf{P}_{\mathrm{S}}\end{array}$ & $\begin{array}{c}\text { Total } \\
\mathbf{P}_{\text {out }}\end{array}$ & \\
\hline $\mathrm{SO}_{4}^{2-}$ & $120 \times 10^{6}$ & $710 \times 10^{3}$ & $330 \times 10^{3}$ & $?$ & $>330 \times 10^{3}$ & $\leq 400 \times 10^{3}$ \\
\hline $\mathrm{Cl}^{-}$ & $9.6 \times 10^{6}$ & $97 \times 10^{3}$ & $26 \times 10^{3}$ & $?$ & $>26 \times 10^{3}$ & $\leq 70 \times 10^{3}$ \\
\hline $\mathrm{Na}$ & $78 \times 10^{6}$ & $290 \times 10^{3}$ & $220 \times 10^{3}$ & $25 \times 10^{3}$ & $245 \times 10^{3}$ & $45 \times 10^{3}$ \\
\hline $\mathrm{Al}$ & $1.5 \times 10^{6}$ & $2.6 \times 10^{3}$ & $4.1 \times 10^{3}$ & $110 \times 10^{3}$ & $114 \times 10^{3}$ & - \\
\hline $\mathrm{Cr}$ & $12 \times 10^{3}$ & 23 & 32 & 160 & 392 & - \\
\hline $\mathrm{Mn}$ & $33 \times 10^{3}$ & 370 & 90 & $6.6 \times 10^{3}$ & $6.7 \times 10^{3}$ & - \\
\hline $\mathrm{Fe}$ & $650 \times 10^{3}$ & $2.8 \times 10^{3}$ & $1.8 \times 10^{3}$ & $110 \times 10^{3}$ & $112 \times 10^{3}$ & - \\
\hline $\mathrm{Zn}$ & $9.3 \times 10^{3}$ & 330 & 260 & 200 & 460 & - \\
\hline Mo & $17 \times 10^{3}$ & 77 & 47 & 5.4 & 52 & 25 \\
\hline $\mathrm{Pb}$ & $10 \times 10^{3}$ & 46 & 27 & 38 & 65 & - \\
\hline
\end{tabular}

$\lambda_{A}$-the reciprocal of the water residence time, year-1: $\lambda_{A}=Q_{A} / V=2.8 \cdot 10^{-3}=$ $1 / 356$ years (QA-Angara outflow, $\sim 60 \mathrm{~km}^{3} /$ year; $\mathrm{V}$-volume of the Lake water body, $21,700 \mathrm{~km}^{3}$ ).

Having introduced some assumptions concerning the quality of initial data we have got a final utterly simplified linear relationship for $\mathrm{t}<50$ years

$$
C / C_{0}=1+\left(\Delta P / m_{0}-\lambda_{A}\right) t
$$

which is valid for time $t+50$ years from the zero point 1980 (regarding to time of collecting the most of relative data); $C, C_{0}$-average chemical concentrations in the Lake water in time $t$ and $t 0$ resp.

\subsection{Forecast Assessments}

Calculation by the model were performed under the most conservative terms for $m(t)$ : fixed mass input value ( $\mathrm{Pin}=\mathrm{Pa}+\mathrm{Pr}+\mathrm{P} \tau=$ const. $)$ and negligable sedimentation (Pout $=\mathrm{PA}>>\mathrm{PS}$, Table 5 ). The value of $\Delta \mathrm{P}$ was estimated by data obtained by the end of 1980-s and was "switched on" in $1980(t=0)$.

According to the data in Table 5 only $\mathrm{SO}_{4}^{2-}, \mathrm{Cl}^{-}, \mathrm{Na}$ and Mo satisfy the condition $\Delta \mathrm{P}>0$ (that is Pin $>\mathrm{PA}+\mathrm{PS}$ ), which means that there might be accumulation of these substances in the Lake water body.

Using this relationship semiquantative estimations of change trends were made for $\mathrm{SO}_{4}^{2-}, \mathrm{Cl}^{-}, \mathrm{Na}^{+}, \mathrm{Mo}$ (Figure 3). Conservative estimations of growth rate of their average concentrations in the Lake waters occurred to be respectively $1 \%, 3 \%, 7 \%$ and $2 \%$ in every 10 years.

Thus, retrospective assessment with regard to industrial releases in the Lake basin since early 1940s proves that the original base levels of mineral components in the Lake still remain undisturbed and represent the natural ("preindustrial") hydrochemical state of one of the cleanest Lakes in the world. 


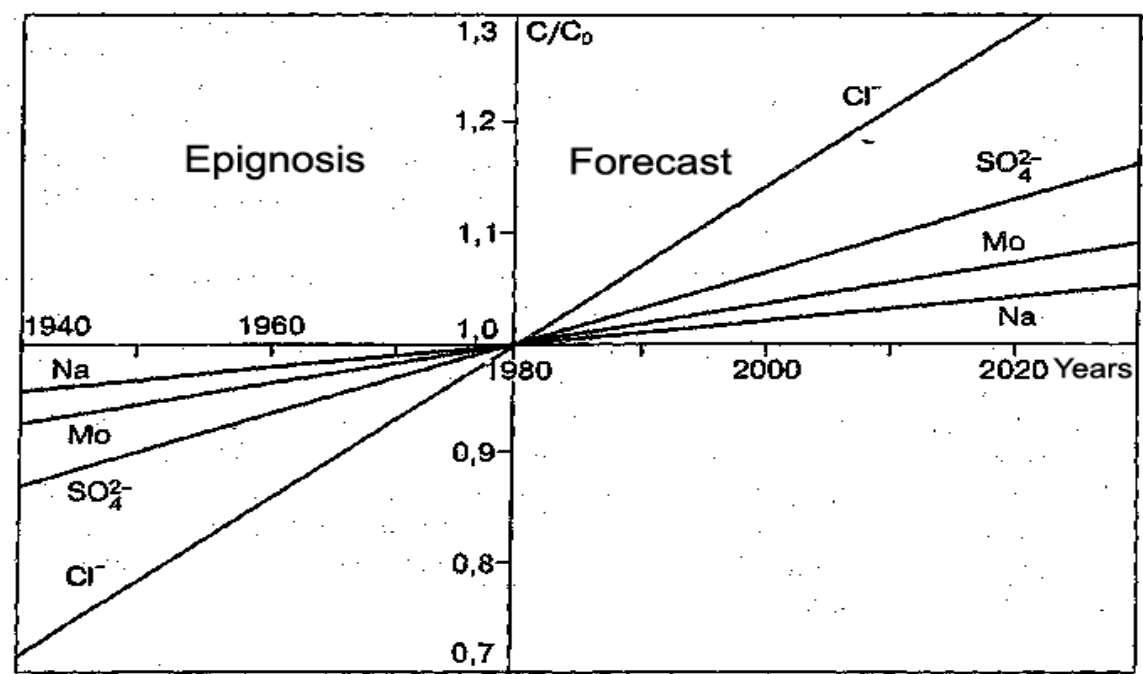

Figure 3. Predicted changes of $\mathrm{SO}_{4}^{2-}, \mathrm{Cl}^{-}, \mathrm{Na}$ and $\mathrm{Mo}$ concentrations in Lake Baikal waters.

\section{Eco-Geochemical Monitoring of Lake Baikal Geosystem}

\subsection{Basic Concepts}

We define eco-geochemical monitoring of the Lake Baikal geosystem as a system of periodic observations on chemical substences in the Lake geosystem's main components: Lake body and tributary waters, precipitation on the Lake and its catchment area, bottom sediments, catchment area soils, aquatic and terrestrial (in coastal areas) biota specimen.

The general goal of the eco-geochemical monitoring is to obtain necessary and sufficient knowledge for environmental management. This involves a quantitative estimation of current and forseeable man-made influence on natural (background, "preindustrial") element concentrations in the environments.

We adopted a conceptual definition for monitoring of man-made environment changes: a system of observations, assessment and forecast of environment conditions for scientific and information support of environment quality management (Figure 4) [5].

We should explain phase contents in the "Monitoring of anthropogenic pollution of the environment" unit (Figure 4) in order to design eco-geochemical monitoring programs for the Lake geosystem.

Observations. A rationale for the program of the eco-geochemical monitoring comes down to a brief analysis of goals and objectives for monitoring of chemical (element) composition of basic environment components inside a geosystem under consideration. The rationale should be based on all relevant knowledge to select chemicals under control and their sampling rates (periods). The suggested programs should provide sufficient volume of data for the "Estimate" and "Forecast" phases according to requirements of "Decision support system" unit.

Assessment of the environmental condition. We define eco-geochemical state of natural environment by comparing concentrations of chemical elements in a 


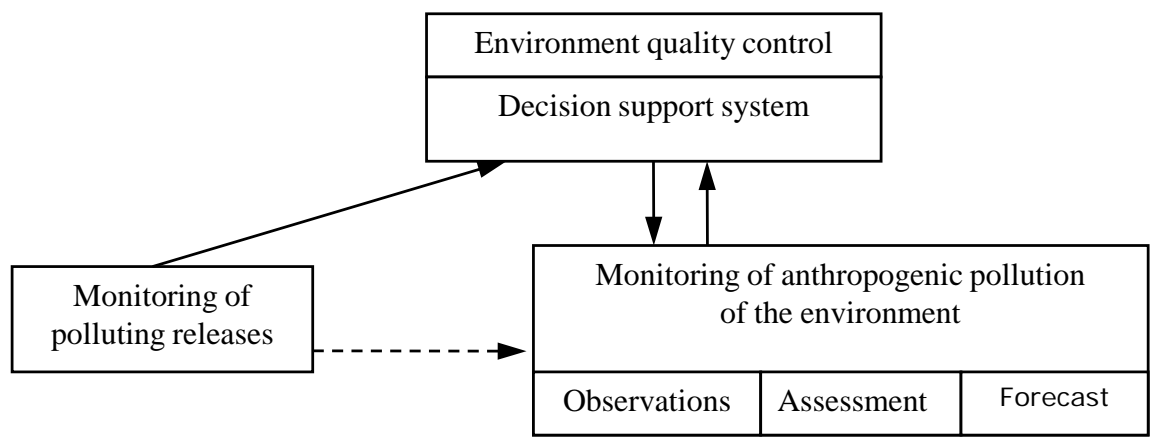

Figure 4. Environmental pollution monitoring framework for environmental quality control.

relevant compartment with their natural concentrations-"clarks" or local levels, usually referred to as natural ("preindustrial") background.

Assessment of eco-geochemical condition of a natural geosystem must answer two basic questions:

- Is there a significant increase of the natural ("preindustrial") geochemical background due to anthropogenic or other influence?

- Whether the detected changes (trends) break former geochemical background of the geosystem?

The latter question can be answered by using predicting calculations made in the "Forecast" phase.

Forecast. Essentially, this phase is the key step to solve the basic task of monitoring, because predicting models are used to arrange both available data and to put requirements to the monitoring system. The output of the "Forecast" phase would be crucial for the "Environment quality management" unit (Figure 4). In that way, scientific rationale for monitoring programs should be based on already known facts about the monitored subject.

\subsection{Monitoring of the Lake Waters}

Taking into account peculiarities of Lake water exchange and formation of its chemistry condition we have identified specific hydrochemical zones and areas of the Lake: deep (pelagic) waters of South, Middle and North Baikal; trophogenic and dynamic layer in a pelagic area of each basin ( 100 m depth); areas of possible anthropogenic impact (Baikalsk PPM, Selenga shallows, Barguzin bay and other); bottom layer (from a few meters above the bottom to 0.1 depth in the observation site). Estimates of the basic parameters of water monitoring program were based on the analysis of the expected rates of changes in the hydrochemical regime in each specific zone (Table 6).

\subsection{Monitoring of Tributeries}

The main contribution to the total chemical runoff to the Lake is made by Selenga, Upper Angara and Barguzin. Expert assessment shows that the growth of anthropogenic chemical runoff in current time can be no more than $20 \%$ per 
decade. Based on this assessment, Table 7 shows recommended intervals between sampling runs for four groups of tributaries. In this scheme, the annual observation program would include estuarine areas of just 3 - 4 rivers in average. Note that detailed (10 - 15) sampling surveys per year in regular time intervals over the main hydrological phases on one tributary river are much more valuable than fragmentary and chaotic sampling at the same time on several tributaries.

\subsection{Monitoring of Aquatic Biota}

Mass species of zooplankton-epishura (Epischura baicalensis Sars.) and macrohectopus (Macro-hectopus branickii Dyb.) - can serve as suitable objects for monitoring of trace elements in Lake Waters. Mollusk Benedictia baicalensis is the most appropriate object for monitoring of contamination of littoral zones with high anthropogenic impact because it is able to accumulate slow pollution changes throughout their life span. Fish and seal tissues have the same integrating ability [5].

We estimate periods between sampling runs of monitored hydrobionts to be 5 - 10 years, depending on monitoring area (Table 8).

Table 6. Recommended periods of monitoring observations of chemistry conditions in different zones of the Lake Baikal water body, years.

\begin{tabular}{|c|c|c|c|}
\hline $\begin{array}{c}\text { Zone } \\
\text { of the water body }\end{array}$ & $\begin{array}{l}\text { Major chemicals, } \\
\text { trace elements }\end{array}$ & $\begin{array}{c}\text { Biogenic } \\
\text { substances }\end{array}$ & Pollutants \\
\hline \multicolumn{4}{|c|}{ Pelagic areas } \\
\hline Trophogenic layer & $10-12$ & $\left.7-10^{*}\right)$ & $5-7$ \\
\hline $\begin{array}{l}\text { Deep water zones of } \\
\text { three basins }\end{array}$ & $10-12$ & $7-10$ & $5-7$ \\
\hline Bottom layers & $10-12$ & $10-12$ & $7-10$ \\
\hline \multicolumn{4}{|c|}{ Anthropogenic impact areas, near-delta areas of major tributaries } \\
\hline Trophogenic layer & $7-10$ & $5-7^{*}$ & $3-5$ \\
\hline \multicolumn{4}{|c|}{$\begin{array}{l}\text { *) Sampling during the most complete depression in phytoplankton life cycle - Dec.-Feb. } \\
\text { Table 7. Recommended periods between observations runs of tributaries' chemical runo } \\
\text { to Lake Baikal. }\end{array}$} \\
\hline \multicolumn{2}{|c|}{ Group of tributaries (\% of the total water inflow) } & $\begin{array}{l}\text { The average } \\
\text { annual water } \\
\text { flow, \% }\end{array}$ & $\begin{array}{c}\text { Periods between } \\
\text { chemical runoff } \\
\text { observation runs, years }\end{array}$ \\
\hline \multicolumn{2}{|c|}{$\begin{array}{c}\text { Selenga (50\%), Upper Angara (13.6\%), } \\
\text { Bargusin }(6.6 \%)\end{array}$} & $\sim 70$ & $3-5$ \\
\hline \multicolumn{2}{|c|}{ Snezhnaya (2.6\%), Turka (2.5\%), Tiya (1.9\%) } & $\sim 7$ & $5-7$ \\
\hline \multicolumn{2}{|c|}{ Tompuda (1.5\%), Kika (1.4\%), Khara-Murin (1.4\%) } & $\sim 4$ & $7-10$ \\
\hline \multicolumn{2}{|c|}{ Others $(<1 \%$ each one $)$} & $<20$ & $10-12$ \\
\hline
\end{tabular}


Table 8. Recommended periods between monitoring observations of pollutants and chemical elements in Lake Baikal aquatic biota.

\begin{tabular}{ccc}
\hline \multirow{2}{*}{ Species } & \multicolumn{2}{c}{ Periods, years } \\
\cline { 2 - 3 } & Pelagial & Littoral \\
\hline $\begin{array}{c}\text { Zooplankton (Epischura baicalensis Sars., } \\
\text { Macro-hectopus branickii Dyb.) } \\
\text { Mollusk Benedictia baicalensis } \\
\text { Fish, seal }\end{array}$ & $\mathbf{3}-\mathbf{5}$ & - \\
\hline
\end{tabular}

\subsection{Monitoring of Atmospheric Fallout}

For monitoring of all input routs of chemicals in atmospheric precipitation into regional environments we proposed a 4-year observation cycle with the following sampling surveys lasting 1 year each:

1) precipitation on the water surface in warm seasons;

2) snow on the ice cover;

3) precipitation in coastal areas;

4) precipitation in background areas in the catchment area.

\subsection{Monitoring of Bottom Sediments}

Taking into account the sedimentation rate in the near-delta areas of the main tributaries of the Lake, determination of the chemical composition of the upper layer $(\sim 10 \mathrm{~mm})$ of natural bottom sediment can be done simultaneously with the relevant hydrochemical survey in these areas, or with monitoring of chemical runoff, i.e. once in 3 - 10 years (Table 6, Table 7).

The main difficulty in monitoring of sediments is a vast variability of pollutant concentrations over a monitoring area and in time. The attempt to perform eco-geochemical monitoring of pelagic bottom sediments by "immediate" observations of the chemical composition of some sediments' layer seems to be hopeless. The reason is the extremely low sedimentation rate in deep zones of the Lake: the average rate of sedimentation in these zones is about $0.3 \mathrm{~mm} /$ year of natural sediment, which corresponds to the flow of dry mass about 7 $\mathrm{mg} / \mathrm{cm}^{2}$.year while estimates range $3-18 \mathrm{mg} / \mathrm{cm}^{2}$.year [26].

In this situation, according to world experience (see, for example, [27]), a promising methodology for monitoring pelagic bottom sediments was to select the deposition flux of suspended material using a set of sedimentation traps. They are usually installed on three depths: about $50-100 \mathrm{~m}$, at an average depth and 20-50 $\mathrm{m}$ above the bottom. With a minimum flow of about $3 \mathrm{mg} / \mathrm{cm}^{2}$.year a trap at a 6-month exposure enable to collect $10-20 \mathrm{~g}$ dry suspended material that would be well enough for almost all kinds of chemical analysis. As an optimum monitoring schedule, we would recommend sampling network in 2-3 points in pelagic area of each Lake basin, with the 3-years sampling cycle (by one year in each basin) performed at every $5-7$ years. 


\section{Conclusion}

- Estimates of the water base line concentrations of trace elements (dissolved forms) in the Lake show that in terms of trace elements, Lake Baikal is one of the purest water re-servoirs on the Earth.

- Trace element content in Baikal aquatic biota corresponds to biogeochemical back-ground levels inherent of pure fresh waters hydrobionts. The studies revealed no effect of increasing accumulation upward the food chain from plankton to Baikal seal for all elements measured (except $\mathrm{Rb}$ ). Tissues and organs of Baikal fishes being strong concentrators of trace elements could serve as bioindicators for monitoring of trace elements in the Lake water body.

- Given the state of knowledge as of 1995, output part of the element mass budget in the Lake can not be reliably estimated due to the lack of data on removal of dissolved ele-ment species from the waterbody to bottom sediments with settling particulate substances. Riverine inflow of particulate matter is the main contributor to sedimentation of chemicals.

- Estimates based on a simple mass-balance model have revealed that the current biogeochemical state of Lake Baikal can be determined as undisturbed natural ("pre-industrial") baseline levels of trace elements in the Lake waterbody. Major input and output constituents of element mass budget, i.e., river inflow, precipitation, Angara outflow and sedimentation should be the priority subjects of monitoring biogeochemical state of Lake Baikal.

- The general goal of the eco-geochemical monitoring is to obtain necessary and sufficient knowledge for environmental management.

- Monitoring space-time programs for the Baikal Lake geosystem are proposed taking in-to account peculiarities of the Lake water exchange and formation of its constituents' chemistry conditions.

\section{References}

[1] Tauson, L.V. (1985) Current Problems of Technogenesis Geochemistry. Proc. of the 1st All-Union Symp. "Geochemistry of Technogenesis", Irkutsk, 29-31 October 1985, V-1 Irkutsk, 5-20 (In Rus.)

[2] Perelman, A.I. (1984) Theoretical Aspects of Techogenic Migration. Study of Methods of Technogenic Geochemical Deviations. Moscow, 3-8 (In Rus.)

[3] Ivanov, V.V. (1994) Environmental Geochemistry of Elements. Book 1. "Nedra", Moscow. (In Rus.)

[4] Izrael, Jn.A. (1984) Ecology and Environmental Control. 2nd Edition, "Gidrometeoizdat", Moscow. (In Rus.)

[5] Vetrov, V.A. and Kuznetsova, A.I. (1997) Trace Elemets in the Environment of Lake Baikal Region. Novosibirsk Izd. Sib. Branch of Rus. Acad. Sc. (In Rus.)

[6] Vetrov, V.A., Kuznetsova, A.I. and Sclyarova, O.A. (2013) Chemical Elements' Base-Lines in Lake Baikal Water. Geography and Natural Resources, № 3, 41-51.

[7] Afanasiev, A.N. (1982) Water Resources and Water Budget of Lake Baikal. "Nauka", Novosibirsk. (In Rus.) 
[8] Verbolov, V.I. and Shimaraev, M.N. (1972) About the Water Exchange in Lake Baikal. Proc. of Inst. of Siberia and Far East Geography, Irkutsk, No. 36, 41-47. (In Rus.)

[9] Kuznetsova, A.I., Vetrov, V.A., et al. (1994) Determination of Trace Elements in the Environment. Novosibirsk, (Ecology Ser., N 30). (In Rus.)

[10] Falkner, K.K., Measures, C.I., Herbelin, S.E. and Edmord, J.M. (1991) The Major and Minor Element Geochemistry of Lake Baikal. Limnology and Oceanography, 36, 413-423.

[11] Falkner, K.K., Church, M., Measures, C.I., et al. (1997) Minor and Trace Element Chemistry of Lake Baikal, Its Tributaries, and Surrounding Hot Springs. Limnology and Oceanography, 42, 329-345.

[12] Suturin, A.N., et al. (2003) Preparation and Assessment of a Candidate Reference Sample of Lake Baikal Deep Water. Spectrocimica. Acta, Part B, 58, 277-288.

[13] Mysovskaya, I.N., et al. (2005) Determination of Trace and Minor Elements in Fresh Water Using Magneting Sector ICP-MS: Application to Lake Baikal Water. Proceedings of the 4 International Conference on Inorganic Environmental Analysis, Pardubice, 224-228.

[14] Sclyarova, O.A. (2011) The Distribution of Trace Elements in the Water Column of the Middle Baikal. Geography and Natural Resources, № 1, 153-159. (in Rus.)

[15] Lomonosov, I.S., Grebenshchikova, V.I., Sclyarova, O.A., et al. (2011) Toxic (Mercury, Beryllium) and Nutrient (Selenium, Fluorine) Elements in Aquatic Ecosystems of the Baikal Natural Territory. Water Resources, 38, 193-204. (In Rus.)

[16] Leermakers, M., Menleman, C. and Baeyens, W. (1996) Mercury Distribution and Fluxes in Lake Baikal. In: Baeyens, W.W., Ebinghaus, R. and Vasiliev, O., Eds., Global and Regional Mercury Cycles. Sources, Fluxes and Mass Balances, Dordrecht; Boston; London: Kluwer Acad. Publishers, NATO ASI, ser. 2, v. 21, 303-315.

[17] Yaroshevsky, A.H. (1990) Clarks of Geosphera. Handbook on Geochemical Methods in Mineral Resources Prospecting. "Nedra”, Moscow, 7-14 (In Rus.)

[18] Korzh, V.D. (1991) Geochemistry of Elements in Hydrosphera. "Nauka”, Moscow. (In Rus.)

[19] Markert, B. (1994) Inorganic Chemical Fingerprinting of Environment: "Reference Freshwater"-A Useful Tool for Comparison and Harmonization of Analytical Data in Freshwater Chemistry. Fresenius J Anal. Chem., 349, 697-702.

[20] Gaillardet, J., Viers, J. and Dupre, B. (2003) Treatise on Geochemistry. Trace Elements in River Waters. Elsevier Ltd., Vol. 5, 225-272.

[21] Ostromagilsky, A.Kh., Vetrov, V.A., et al. (1981) Trace Elements in the Atmosphere of Rural Terrestrial and Oceanic Areas. Obninsk, International Centre of Data, (Review, Env. Pollut. Control Ser.). (In Rus.)

[22] Mur J.B., Rammamurty (1987) Trace Metals in Natural Waters. "Mir”, Moscow. (Translated from Eng. into Rus.)

[23] Vinogradov, A.P. (1989) Ocean Geochemistry. "Nauka”, Moscow. (In Rus.)

[24] Turekian, K.K. and Wedepohl, K.H. (1961) Distribution of the Elements in Some Major units of the Earth's Crust. Bull. Geol. Sos. Amer., 72, 175-190.

[25] Votintsev, K.K., et al. (1978) Primary Produce. In: G. I. Galasy, \& K. K. Votitsev (Eds.,) Problems of the Baikal Lake, "Nauka”, Novosibirsk, 124-145. (In Rus.)

[26] Edgington, D.N., et al. (1991) Sedimentaition Rates, Residence Times and Radionuclide Inventories in Lake Baikal from $137 \mathrm{Cs}$ and $210 \mathrm{~Pb}$ in Sediment Cores. Na- 
ture, 350, 601-604.

[27] Sigg, L., Strum, M. and Kistler, D. (1987) Vertical Transport of Heavy Metals by Settling Particles in Lake Zurich. Limnol. Oceanogr, 32, 112-130. 